Annals of Warsaw University of Life Sciences - SGGW

Land Reclamation No 41 (2), 2009: 83-93

(Ann. Warsaw Univ. of Life Sciences - SGGW, Land Reclam. 41 (2), 2009)

\title{
Advantage of Bayesian approach to geotechnical designing
}

\author{
KAZIMIERZ GARBULEWSKI ${ }^{1}$, STANISŁAW JABŁONOWSKI ${ }^{2}$, \\ SIMON RABARIJOELY ${ }^{1}$ \\ ${ }^{1}$ Department of Geotechnical Engineering, Warsaw University of Life Sciences, Poland \\ ${ }^{2}$ Department of Informatics, Warsaw University of Life Sciences, Poland
}

\begin{abstract}
Advantage of Bayesian approach to geotechnical designing. The paper addresses the possibility of the Bayesian approach's application to geotechnical engineering. First the principal information on the Bayesian analysis has been presented and its applications to estimate the soil parameters based on the CPT/DMT tests at SGGW Campus in Warsaw afterwards. The CPT/DMT tests had been carried out in order to recognize the geotechnical conditions in the foundations of design campus buildings. The data from two layers of glacial boulder clays have been analysed. The results demonstrate that the Bayesian approach is a useful tool in evaluation of ground properties and estimation of the geotechnical parameters in specified circumstances.
\end{abstract}

Key words: Bayesian approach, estimation of parameters, CPT/DMT tests.

\section{INTRODUCTION}

Designing of engineering structures in accordance with the principles and rules of Eurocode 7 (EN 1997-1) requires taking into account, in addition to the not questionable, the recommendations not fully defined. Certainly, it doesn't derive from the negligence of the Eurocode's authors, but from inadequate and uncertain theoretical basis of past experience to develop clear recommendations. It pushes the designer to take sometimes very risky decisions. The same are the reasons for the decision of allowing designers to choose from three design approaches (DA1, DA2, DA3), which differ in the way of partial distribution coefficients between the actions, the effects of interactions, the nature and strength of materials (Kłosiński 2005). Design calculations' results for checking the limit states of the proposed construction may vary even tens of percent or more, depending on the design approach. Characteristic values of geotechnical parameters may be subject to alteration at the designers' discretion and also at discretion of the geotechnical engineers cooperating with the designers. According to Eurocode 7 the characteristic values should be determined on the basis of a safe estimate of the mean value; the characteristic values can be either $50 \%$ quantile $\left(\bar{x}=x_{50}\right)$ or any other quantile $\left(x=x_{P \neq 50}\right)$, such as e.g. lower or upper quartile of the probability density distribution (Pieczyrak 2009). Frank et al. (2004) discuss the main factors affecting the estimation of characteristic values of geotechnical parameters. Selecting decision-making "path" to determine the characteristic value on the basis of statistical analysis depends significantly on the currently accepted practice. One of the possible "paths" that enables the inclusion of additional measurement data and 'a priori' knowledge leads to Bayesian inference's usage. In special 
cases, when the traditional method of designing (calculations, specifications and regulations, experimental models and test loading) can not ensure the structure's security, the observational method can be used. The method, articulated by Peck (Peck 1969), has been applied with success in geotechnical engineering (Daniel 1993; Frank et al. 2004). It should be applied particularly in the designing of structures classified to the third geotechnical category - large objects that require compliance with the conditions of safety without any risk, especially designed in the difficult geotechnical conditions, such as anthropogenic grounds. In the observational method the designing process extends to the period of construction; design solutions are introduced to the project depending on the behavior of the structures under construction. Collection of measurement data systematically expands. Without going into detail it can be seen that the Bayesian approach may be useful to integrate new and existing data and to detect the analyzed phenomena probability's changes. In recent years more and more trials of using Bayesian analysis to solve geotechnical issues are observed. It is because of geotechnical issues' complexity and uncertainty. E.g. data sets still being enlarged have been used in identifying the most likely sources of pollution or in the interpretation the hydraulic permeability's tests(Alén 1998, Alén and Sällfors 1999, Kemblowski and Johnson 2000, Garbulewski et al. 2007).

\section{BAYESIAN APPROACH - PRINCIPLE INFORMATION}

Bayesian approach differs from the classical statistical inference. In the classical mathematical statistics a sample taken from a population stands for the basis of reasoning. The necessary information about the population in the form of assessments of real information, such as evaluation of the characteristics of a selected parameter of the population is determined on the basis of the sample and only of it. Parameter can be, for example the expected value, standard deviation, the fraction of elements of a particular type or another. To calculate such an assessment an idea of point estimator and of interval estimator can be adopted. To determine the parameters' assessments of the specified populations in the Bayesian approach, beside data collected into the sample, socalled 'a priori' information is to be put to use. If such information is available and objective, the Bayesian method can be competitive with the classical method of statistical inference. A priori information can be: the conclusions of studies carried out earlier (providing no complete data on samples from which these conclusions have been derived are available, otherwise the data could be attached to the current sample), a certain expertise, which is difficult to strictly formally infer. A population parameter for which the Bayesian method may be used can be e.g. the expected value of a ground layer's characteristic, such as $\mathrm{E}_{\mathrm{D}}$ dilatometer module obtained as the result of DMT. A priori knowledge can 
descend from other similar classes of ground (Baxter et al. 2008), an expertise (reasonable enough) can be used, too. The Bayesian method is a very welldeveloped one if the characteristic under examination has a normal or lognormal distribution (Aczel 2000). A significant number of geotechnical parameters follow such distributions (Alén 1998). For other probability distributions applying the described approach is more difficult, but possible to use, too. Described reasoning is derived from Bayes theorem, which, in the most basic form, shows the relationship between the conditional probability of event A under the condition $\mathrm{B}$ and the conditional probabilities of events $\mathrm{B}$, provided $\mathrm{A}$ and provided the event A's complement and also the probabilities of the event A and its complement. This formula is then generalized for the situation where the presence of many exclusive events is being considered, not just only two events A and its complement. However, we are interested in the case of the parameters of the continuous probability distribution, for which the Bayesian model assumes the form shown onwards (see (1)). Very significant difference in the Bayesian approach in comparison to the classical one is that the parameters of the population that we want to estimate, such as the parameter $\theta$ in the formula below, are treated as random variables. In the classical approach the parameters are defined, but of unknown values. For random variables with continuous probability distribution the Bayes theorem can be described as follows: $f(\theta \mid x)=\frac{f(x \mid \theta) \cdot f(\theta)}{\int_{\Omega} f(x \mid \theta) \cdot f(\theta) d \theta}$

where:

$f(\theta)$ here means the a priori probability density function of the parameter $\theta$, while $\mathrm{f}(x \mid \theta)$ is a "function of credibility", that is the conditional probability density function of an observation at a given value of $\theta$, equal q. $\Omega$ symbol used in the integral means a set of possible values of the estimated parameter $\theta$. On the left side of the formula (1) there is the "a posteriori" probability density function of the parameter $\theta$, after observing the outcome $\mathrm{x}$ with the sample. Thus, on the Bayes theorem basis the a priori probability density function of the parameter $\theta$ is updated, using information from the sample. Appointment the a posteriori probability density of the specified parameter is not difficult in the case of normal distributions, which often occur in practice. The presented Bayes theorem provides a very valuable and practical opportunity of sequential new information's incorporation to infer about the parameter. The a posteriori knowledge of the parameter $\theta$ probability is treated as the a priori probability of this parameter in the consecutive step of reasoning. If the whole information dose could be included at once, the classical approach would be more adequate. However, the experiment can be compared with the Bayesian approach. It turns out that it gives similar results. By the way, we learn that the order of including information's doses into the calculations, in the Bayesian approach, is optional. 
Let us now discuss an event important in practice, especially in geotechnical practice, when a parameter $\theta$ being estimated is the expected value of a normal population. Let us assume that the population standard deviation, $\sigma_{0}$, is known. If we use the a priori knowledge about the average $\theta$ (treated as a random variable) of the population from which it follows that $\theta$ is normally distributed with parameters $m_{1}$ and $\sigma_{1}$, and if the average obtained from an n-element sample is $m_{2}$, than the a posteriori distribution of the random variable $\theta$ is also normal with the parameters $m$ and $\sigma$ calculated as follows:

$$
\begin{aligned}
& m=\frac{\left(1 / \sigma_{1}^{2}\right) \cdot m_{1}+\left(n / \sigma_{0}^{2}\right) \cdot m_{2}}{\left(1 / \sigma_{1}^{2}\right)+\left(n / \sigma_{0}^{2}\right)} \\
& \sigma=\sqrt{\frac{1}{\left(1 / \sigma_{1}^{2}\right)+\left(n / \sigma_{0}^{2}\right)}}
\end{aligned}
$$

Given such results, a corresponding confidence interval for the parameter can be determined. It's called here a credible set of the parameter. For e.g. 0.95 level of probability for this interval it is being calculated as $(\mathrm{m}-1,96 \sigma ; \mathrm{m}+1,96 \sigma)$. It means that the mean of the population (a random variable) will fall into this range with the probability of 0.95 . Recall that the classical confidence interval is random and covers a well-defined but unknown population mean with a specified probability, here equal to 0.95 .

\section{BAYESIAN APPROACH IN GEOTECHNICAL PRACTICE}

\section{Identifying the geotechnical conditions for construction foundations}

The Bayesian methodology assumes that we have some preliminary knowledge about the parameters, and this knowledge is then altered after comparing with the data. Using the distribution of 'a priori' and knowledge of the collected sample a modified distribution of the parameter can be formulated. Here, both the original ('a priori') belief and the empirical data obtained from an investigation have been taken into account. Alén and Sällfors (1999) presented the application of Bayesian approach for interpretation of field vane investigations in large thickness of homogeneous weak clays in the valley of the River Göta. In determining the shear strength of clays a procedure consisting of the following two stages was adopted: I stage - the results analyzed were estimated assuming a probability distribution on the basis of test results of samples from three profiles of research, II stage - the results of the first stage was extended by adopting the statistical analysis results from five additional profiles. The procedure adopted led to the receipt of the changes already in the middle of a very small extent, and only a moderate reduction in standard deviation. The authors proposed a formula to determine the value of the characteristic undrained shear strength $\left(c_{u, c h a r}\right)$ in the form: 
$c_{u, \text { char }}=c_{u}(1-v / \sqrt{n})$

where:

$c_{u}$ - average value of research results, $v$ - diagnostic value of the coefficient of variation (deviation),

$\mathrm{n}$ - number of tests.

Formula (4) was proposed as a compromise between a complete statistical analysis and a pragmatic approach.

Assuming the indisputable advantages of Bayesian approach and the own experiences with its existing applications in geotechnical issues it is proposed to use Bayesian analysis in planning studies to develop the geotechnical model and to identify ground conditions in the foundations of the designed buildings. General geological and hydrogeological conditions, with no precise boundaries of layers and the types and soil states in the ground of the designed buildings, as well as the location of ground water table, can be established by non-invasive methods such as e.g. electro-resistance, seismic or GPR surveying. The results of non-invasive methods can be regarded as preliminary knowledge of the conditions of the foundation, which will be used to plan the needed number of geotechnical soundings (CPTU and/or DMT). Longterm and costly drilling, which are necessary, will be treated as a reference for the verification of the results obtained from the CPTU/DMT tests.

\section{Selection of parameters in geotechnical designing}

Principles proposed by Bayes were used to estimate the undrained shear strength and soil stiffness in the subsoil of the newly constructed objects in the SGGW campus. Among the sediments deposited in the ground tested the five geological packages were distinguish for which, depending on the soil types and conditions the geotechnical layers were established (Fig. 1). Bayesian method

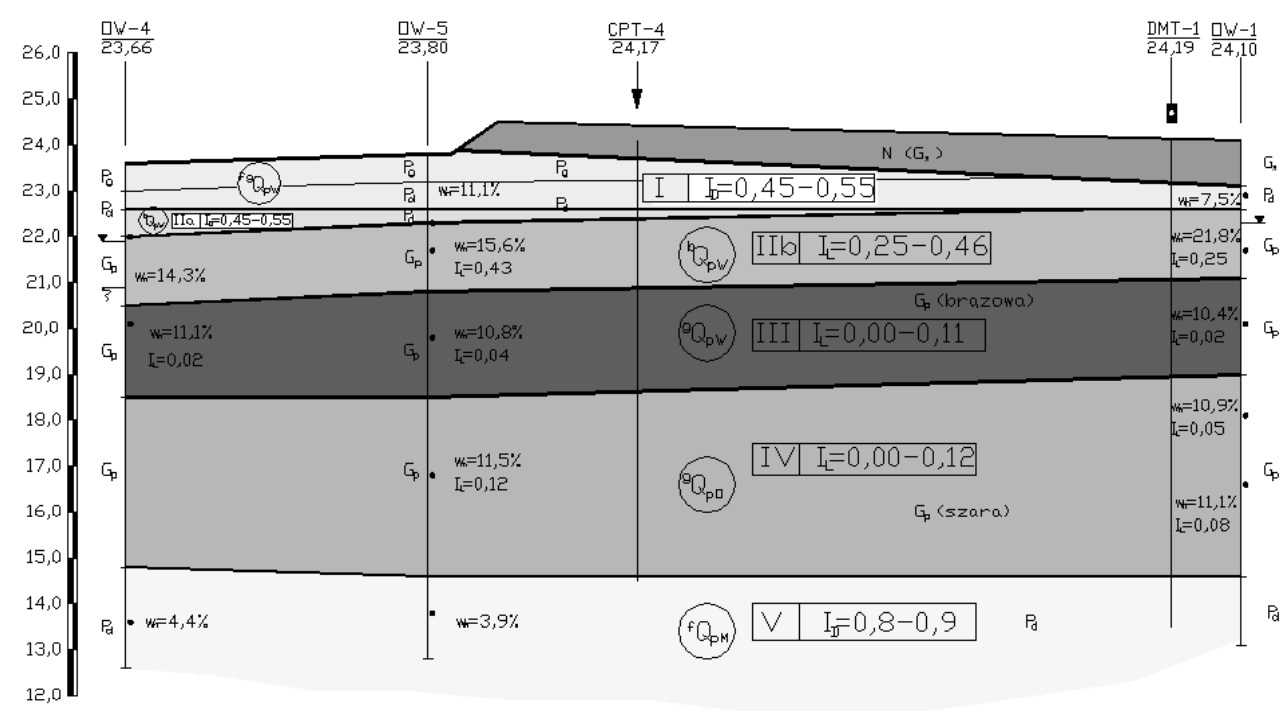

FIGURE 1. Geotechnical cross-section of the ground at SGGW Campus (Geotechnical documentation... 2001) 
was used to estimate the geotechnical parameters in two layers, namely: the layer no. III - brown clay of the Warta glaciation $\left({ }^{\mathrm{g}} \mathrm{QpW}\right)$, mainly sandy clay of low plasticity with the $\mathrm{I}_{\mathrm{L}}=0-0.11$ (stiff); the layer no. IV - gray clay of the Odra glaciation $\left({ }^{\mathrm{g}} \mathrm{QpO}\right)$, mainly sandy clay with $\mathrm{I}_{\mathrm{L}}=0-0.12$ (stiff), containing some Scandinavian boulder.

Detailed geotechnical conditions within the proposed building area were recognized using the CPT and DMT tests. The cone penetration test (CPT) is standard, well know method commonly use for recognize of geotechnical condition. The tests at SGGW campus were performed in 5 profiles to the depth of approximately $11 \mathrm{~m}$ (Fig. 2). During the standard cone penetration with constant speed of $2 \mathrm{~cm} / \mathrm{s}$ the cone resistance $\left(\mathrm{q}_{\mathrm{c}}\right)$, sleeve friction resistance $\left(f_{s}\right)$ and friction coefficient $\left(R_{f}\right)$ were measured. The CPT test results were applied to determine undrained shear strength $\left(t_{\mathrm{fu}}\right)$ distribution in foundation of the SGGW campus building according to the formulae:

$\tau_{f u}=\frac{q_{c}-\sigma_{v o}}{N_{k}}$

where: $s_{\mathrm{vo}}-$ total overburden pressure $\mathrm{N}_{\mathrm{k}}$ - empirical cone coefficient $\left(\mathrm{N}_{\mathrm{k}}=20\right.$ was assumed in analysis presented).

The DMT test is based on the subsoil penetration by the flat blade. In the selected depths the measurements of the working gas pressure on the membrane are undertaken. During the research the two parameter measurements are possible: pressure A (taken at the first contact of the soil with the membrane) and pressure B (taken after pushing the membrane with the air transported by the internal pneumatic tubing). They are used together with the effective vertical stress $\sigma^{\prime}{ }_{v o}$ and water pores pressure $u_{0}$ to calculate further two corrected pressures: $p_{0}, p_{1}$ and three DMT indexes as follows (Briaud and Miran 1992, Lutenegger
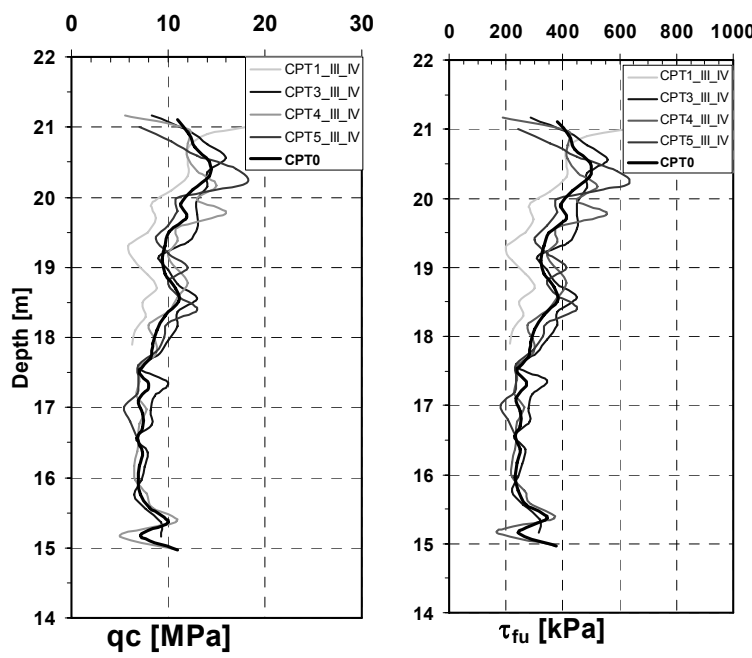

FIGURE 2. Profiles of cone resistance qc and undrained shear strength tfu in ground of SGGW campus (Geotechnical documentation... 2001) 
1988, Lutenegger and Kabir 1988, Previously described Bayesian Marchetti 1980):

Material index:

$$
I_{D}=\frac{p_{1}-p_{o}}{p_{o}-u_{o}}
$$

Horizontal earth pressure index:

$$
K_{D}=\frac{p_{o}-u_{o}}{\sigma_{v o}^{\prime}}
$$

Dilatometer modulus:

$$
E_{D}=34.7 \cdot\left(p_{1}-p_{o}\right)
$$

Example results of the DMT tests at the SGGW campus are shown in Figure 3. To the recognition of geotechnical layers the graph clustering algorithm from the dilatometer tests was applied (Rabarijoely et al. 2007). approach has been used in the calculation of a credible set of the parameter (counterpart to the confidence interval). In the case of CPT tests the value of qc has been taken into account. This is the cone resistance, recorded at different depths during successive probes carried out in order to investigate the mechanical properties of a specific layer of soil. In a single layer of the soil measured cone resistance qc is a random variable. This random variable should have a normal distribution because of its size affects a large number of random factors, which can be considered as a set of independent random variables with different directions and with different force affecting the test variable. Results of Bayesian analysis for package III and IV are summarized in the Table 1 . The credible sets (based on the final results of calculations provided)

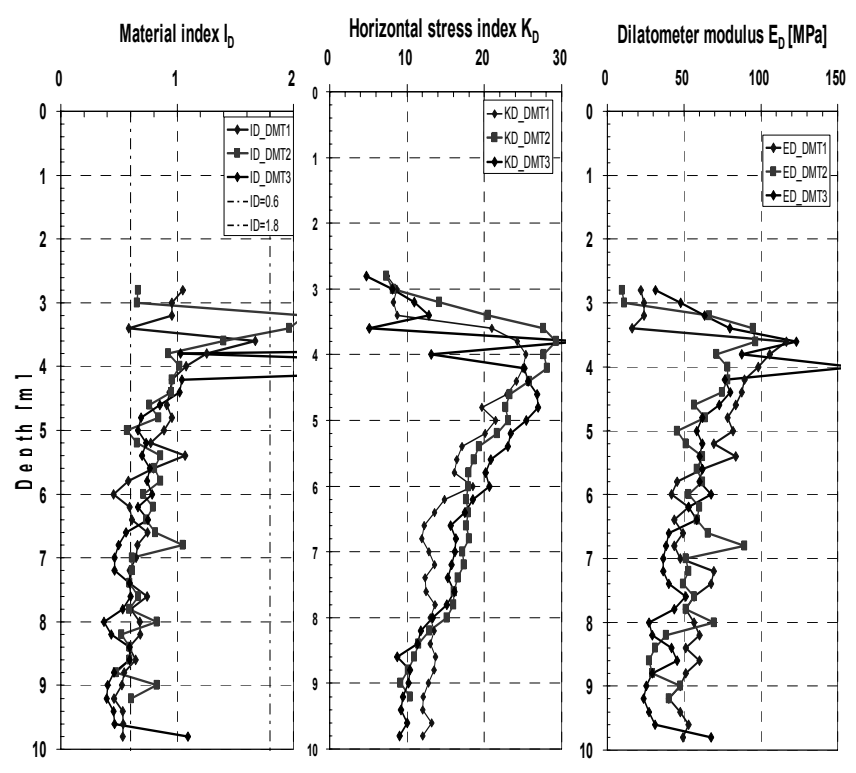

FIGURE 3. Profiles of indexes from DMT tests at SGGW campus (Geotechnical documentation... 2001) 
TABLE 1. Results of Bayesian analysis for package qc values III and IV

\begin{tabular}{|c|c|c|c|c|c|c|}
\hline \multirow[t]{2}{*}{$\begin{array}{l}\text { Packet } \\
\text { No }\end{array}$} & \multirow{2}{*}{$\begin{array}{l}\text { Tests } \\
\text { subsequently } \\
\text { included in the } \\
\text { calculation }\end{array}$} & \multicolumn{3}{|c|}{$\begin{array}{l}\text { Statistical parameters calculated on the } \\
\text { basis of tests for the cone resistance } \mathrm{q}_{\mathrm{c}} \\
\mathrm{MPa}\end{array}$} & \multicolumn{2}{|c|}{$\begin{array}{l}\text { Statistical parameters calculated } \\
\text { for the average cone resistance } \\
\text { qc [MPa] based on Bayesian } \\
\text { approach }\end{array}$} \\
\hline & & average & $\begin{array}{l}\text { Standard } \\
\text { deviation }\end{array}$ & sample size & average & $\begin{array}{l}\text { Standard } \\
\text { deviation }\end{array}$ \\
\hline \multirow{5}{*}{$\begin{array}{l}\text { 目 } \\
\stackrel{\vec{\Xi}}{\Xi}\end{array}$} & CPT1 & 11.82 & 5.70 & 14.00 & 11.82 & 1.52 \\
\hline & CPT 2 & 4.76 & 4.04 & 12.00 & 7.37 & 0.93 \\
\hline & CPT 3 & 12.25 & 2.20 & 13.00 & 10.78 & 0.51 \\
\hline & CPT 4 & 11.81 & 2.51 & 13.00 & 11.14 & 0.41 \\
\hline & CPT 5 & 11.50 & 3.19 & 12.00 & 11.20 & 0.38 \\
\hline \multirow{5}{*}{ 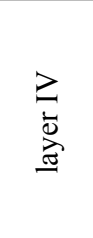 } & CPT 1 & 7.43 & 0.91 & 6.00 & 7.43 & 0.37 \\
\hline & CPT 2 & 12.96 & 3.92 & 17.00 & 8.17 & 0.35 \\
\hline & CPT 3 & 8.80 & 1.71 & 18.00 & 8.44 & 0.26 \\
\hline & CPT 4 & 7.98 & 1.69 & 19.00 & 8.29 & 0.22 \\
\hline & CPT 5 & 8.28 & 2.37 & 11.00 & 8.29 & 0.21 \\
\hline
\end{tabular}

with a probability of 0.95 for average value of qc for the packages III and IV are as following: $(10.463,11.934) \mathrm{MPa}$ for package III and $(7.883,8.6995) \mathrm{MPa}$ for package IV.

In the statistical analysis of the results of DMT readings $\mathrm{A}, \mathrm{B}$ and calculated indicators $\mathrm{I}_{\mathrm{D}}, \mathrm{K}_{\mathrm{D}}$ and module dilatometer $\mathrm{E}_{\mathrm{D}}$ have been taken into account. These quantities can be treated as random variables. Weused 17 studies DMT in layer III of size from 6 to 35 measurements, a total of 239 measurements and 15 DMT research in the layer IV of size from 9 to 33 measurements, a total of 320 measurements. The types of distribution of these random variables have been checked. For the most tests which have been conducted, there was no reason to reject the hypothesis of normality (the Shapiro-Wilk tests suitable for small samples have been applied; they are available e.g. in a package of statistical programs Statgraphics (STATGRAPHICS PLUS V.4.1).

Like for the index $\mathrm{q}_{\mathrm{c}}$ sequential observations were included in subsequent modifications of the results, according to the Bayesian approach. A credible set of the average for each of the tested random variables has been calculated based on the final results of the evaluation. When applying the formulas (2) and (3) the population standard deviation, $\sigma_{0}$, is to be known, which is no the commonly case in the practice. Usually, $\sigma_{0}$ is replaced by its estimates based on a samples' data. This attitude has been used (method 1) but also the second approach (method 2) has been used. In this method in using formulas (2) and (3) the knowledge of $\sigma_{0}$ is assumed. In case of the parameter $\mathrm{K}_{\mathrm{D}}$ in the layer III it has been assumed that the standard deviation is equal to 9.66. This is not a typical in the practice, but it was worthwhile to be able to compare the results of these two approaches. Bayesian 
credible sets obtained for the average of $\mathrm{K}_{\mathrm{D}}$ in the layer III, with the probability of 0.95 are as follows: $(23.015,24.11)$ with the method 1 and $(22.476,24.884)$ with the method 2. If the classical inference could be applied, that is if the data from all probes could be treated as a one large sample, the confidence interval of confidence level 0.95 would be equal to (22.652, 25.101).

A similar analysis was performed for the quantities $I_{D}, E_{D}$, as well as for readings $\mathrm{A}$ and $\mathrm{B}$ in layer III and IV. Differences between results obtained in Bayesian approach and in the classic inference are of the same ratio as for $\mathrm{K}_{\mathrm{D}}$ in the layer III and are not large. Like shown in Tables 2 and 3, the standard deviation of the distribution of the parameters decreases steadily during the subsequent calculations, while the average value has already very small fluctuations.

\section{CONCLUDING REMARKS}

If the geotechnical test parameter having a normal distribution is the characteristic value of the ground layer, the knowledge on this geotechnical parameter may be improved according to the formulas (2) and (3). Other successive portions of the data from, for example subsequent investigations ofDMT, specifyknowledge of the parameter distribution, because in general, they reduce the standard deviation of this distribution. When a credible set of a parameter is created, it can eventually take a specific value, such as the lower edge of the designated range for the value of a characteristic needed in further considerations. Bayesian

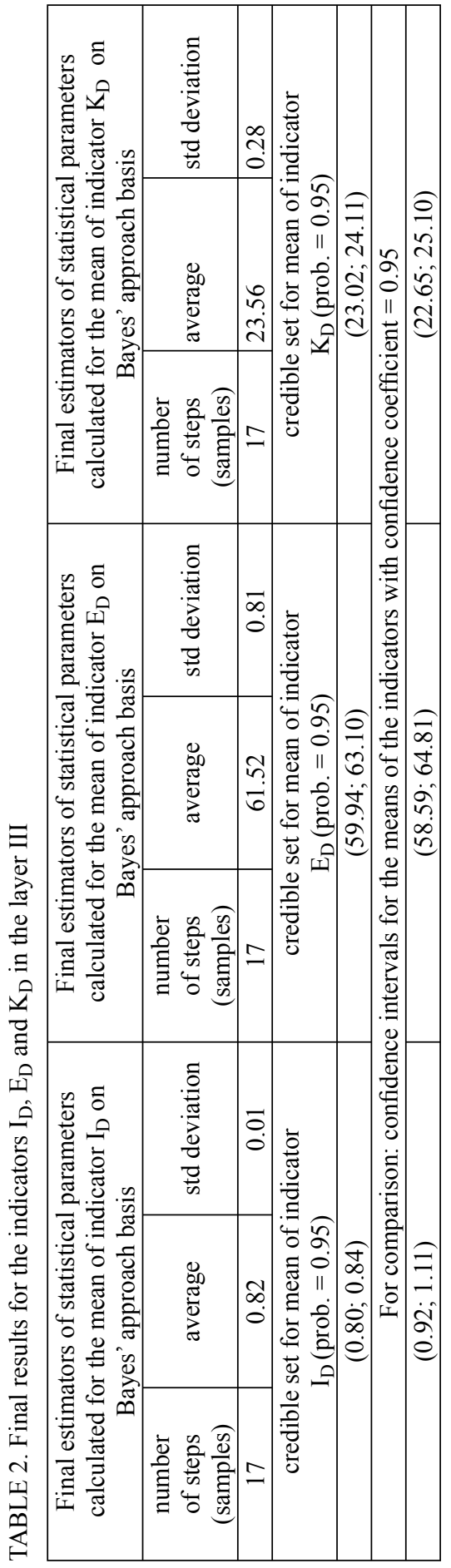




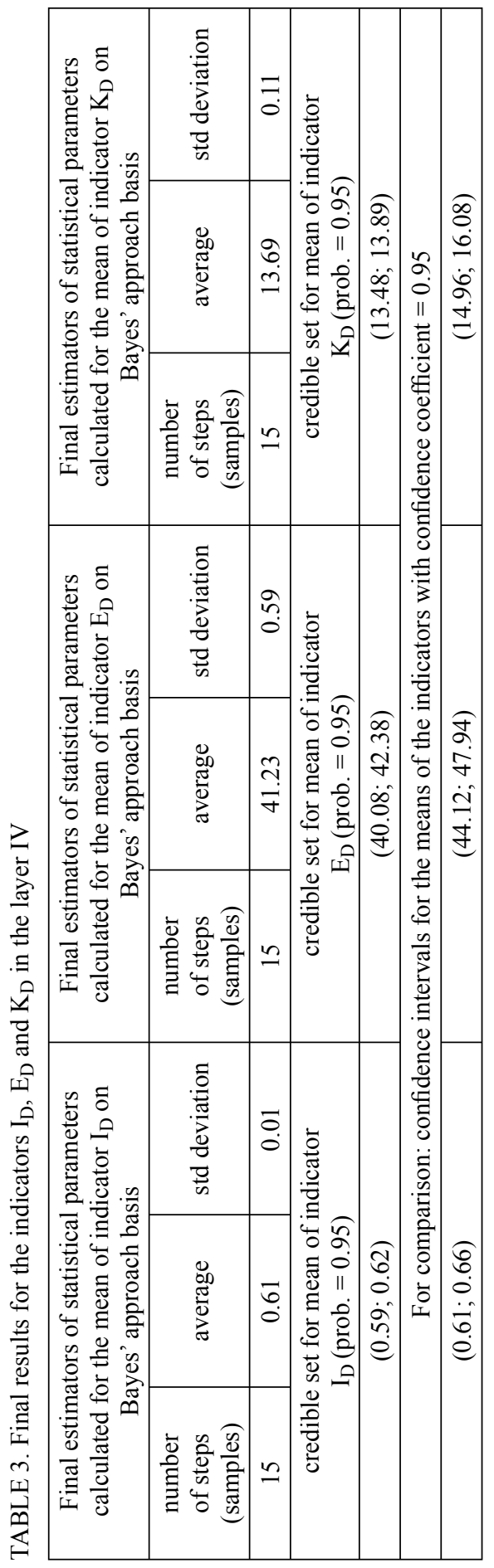

approach should be used when some information is available, but random samples from which it has been derived are already unknown. In this approach this information can be profitable nevertheless and it can improve estimates of the parameters. Otherwise the classical approach can be used and the results will be comparable.

\section{REFERENCES}

ACZELA.D. 2000: Statistics in management. Scientific Publisher PWN, Warszawa (in Polish).

ALÉN C.G. 1998: On probability in geotechnics. Random calculation models exemplified on slope stability analysis and ground-superstructure interaction. $\mathrm{PhD}$ thesis, Chalmers University of Technology, Göteborg.

ALÉN C.G., SÄLLFORS G.B. 1999: Uncertainties in modeling of soil properties. [In:] Barends et al. (eds), Proc. of the EC SMGE: Geotechnical Engineering for Transportation Infrastructure, Balkema, Rotterdam, 303-308.

BAXTER D.J., DIXON N., FLEMING P.R., CROMWELL K. 2008: Refining shear strength characteristic value using experience. Geotechnical Engineering, Issue GE5, 247-257.

BRIAUD J., MIRAN J. 1991: The flat dilatometer test, TX, 77843-3136 USA for The Federal Higway Administration.

DANIEL D.E. (ed.) 1993: Geotechnical practice for waste disposal. Chapman \& Hall, London.

EN 1997-1 Eurocode 7: Geotechnical Design - Part 1: General Rules, CEN, Brussels.

FRANK R., BAUDUIN C., DRISCOLL R., KAVVADAS M., KREBS OVESEN N., ORR T., SCHUPPENER B. 2004: Designers 'Guide to EN 1997-1 Eurocode 7: Geotechnical Design-General Rules, Thomas Telford. 
GARBULEWSKI K., JABŁONOWSKI S., RABARIJOELY S. 2007: Application of Bayesian approach in geotechnical design. Inżynieria Morska i Geotechnika, nr 3, 163-169 (in Polish).

GEOTECHNICAL DOCUMENTATION concerning soil and groudwater conditions in site destined for two laboratorial and educational buildings of Warsaw University of Life Sciences Campus. Department of Geotechnical Engineering, 2001 (in Polish).

KEMBLOWSKI M., JOHNSON M. 2000: Environmental monitoring, modelling and management - Bayesian Belief Networks, Envirosoft, Bilbao, Spain.

KŁOSIŃSKI B. 2005: Review of European standards to geotechnical designing. Geoinżynieria i Tunelowanie, $\mathrm{nr} 02$ (05): 18-27 (in Polish).

LUTENEGGER A. 1988: Current status of the Marchetti dilatometer test. Proc. Int. Sym. on Penetration Testing ISOPT-1. Orlando, 1: 137-155.

LUTENEGGER A.J., KABIR M.G. 1988: Dilatometer C-reading to help determine stratigraphy, [In:] J. de Ruiter (ed.), Proc. of the First International Symposium on Penetration Testing ISOPT-1, Orlando, Balkema, Rotterdam, 1, 549-553.

MARCHETTI S. 1980: In situ tests by flat dilatometer. Journal of Geotech. Eng. Div. ASCE, 106, GT3, 299-321.

PECK R.B. 1969: Advantages and limitations of the observational method in applied soil mechanics. Ninth Rankine lecture, Geotechnique, 19(2): 171-187.

PIECZYRAK J. 2009: Ultimate states and design conditions. XXIV Workshop for Designers of Structures, Vol. I, 247-270 (in Polish).

RABARIJOELY S., BILSKI P., and FALKOWSKI T. 2007: The usage of the graph clustering algorithm to the recognition of geotechnical layers, Annals of Warsaw University of Life Sciences - SGGW. Ann. Warsaw Univ. of Life Sciences - SGGW, Land Reclam., No 38, 2007, 57-68.
STATGRAPHICS PLUS V.4.1,(1994-1999):

Statistical Graphics Corp.

Streszczenie: Zalety wnioskowania bayesowskiego w projektowaniu geotechnicznym. Artykuł przedstawia zalety stosowania podejścia bayesowskiego do projektowania geotechnicznego. W pierwszej części artykułu przedstawiono zasadnicze założenia analizy bayesowskiej i opisano przykłady jej zastosowania w ocenie warunków geotechnicznych posadowienia budowli i doboru parametrów w projektowaniu geotechnicznym. Do obliczeń projektowych Autorzy wykorzystali wyniki badań CPT i DMT przeprowadzone na terenie Kampusu SGGW w Warszawie. Dane z badań dwóch warstw geotechnicznych (glin zwałowych) zostały wykorzystane do określenia wartości charakterystycznych wybranych parametrów geotechnicznych. Analiza statystyczna z zastosowaniem podejścia bayesowskiego doprowadziła do średnich wartości $\mathrm{q}_{\mathrm{c}}$ na poziomie ufności 0,95 które wynoszą dla warstwy III i IV odpowiednio: $(10,463,11,934) \mathrm{MPa}$ i $(7,883,8,6995) \mathrm{MPa}$. $\mathrm{Z}$ analizy danych dylatometrycznych wynika, że średnie wartości parametru $\mathrm{K}_{\mathrm{D}} \mathrm{w}$ warstwie III i IV wynoszą odpowiednio: $(23,015,24,11)$ i $(13,48 ; 13,89)$. Wyniki analiz pokazują, że podejście bayesowskie w pewnych sytuacjach może być wykorzystane do oceny właściwości podłoża i określenia parametrów geotechnicznych.

Acknowledgments: This research was supported by Grant no. N N506 432436 from the Ministry of Science and Higher Education, Warsaw, Poland.

\section{Authors' addresses:}

Kazimierz Garbulewski, Simon Rabarijoely

kazimierz_garbulewskii@sggw.pl, simon_rabarijoely@sggw.pl

Katedra Geoinżynierii

Wydział Inżynierii i Kształtowania Środowiska

SGGW

02-776 Warszawa, ul. Nowoursynowska 159,

Poland

Stanisław Jabłonowski

stanislaw_jablonowski@sggw.pl

Katedra Informatyki

Wydział Zastosowań Informatyki i Matematyki

SGGW

02-776 Warszawa, ul. Nowoursynowska 159,

Poland 